\title{
Kolaborasi Dakwah Ulama dan Umara dalam Perspektif Islam
}

\author{
Ahmad Zuhdi, Ivan Sunata \\ Institut Agama Islam Negeri (IAIN) Kerinci \\ Institut Agama Islam Negeri (IAIN) Kerinci \\ zuhdi69@siswa.um.edu.my
}

\begin{abstract}
Allah Almighty in many verses explains that the obligation in calling on the people is not only imposed on the preachers, but the obligation of the whole people. Among the whole in question is the existence of participation between the Leader and the Ulema. The leader is someone who is given the power to organize and regulate social life in accordance with existing rules and laws, while the scholars are figures who are present in the community as guides and illuminators in practicing aspects of religious teachings that have been ordered by God Almighty and His Messenger. In this study, the author will reveal and answer three research questions, namely: 1) leadership terms in Islam, 2) the preaching of the mandate of allah for the scholars, 3) collaboration of ulama and umara in da'wah.
\end{abstract}

Keywords: Collaboration of Dakwah, Teologian and Leader

\begin{abstract}
Abstrak. Allah swt dalam banyak ayat menjelaskan bahwa kewajiban dalam menyeru umat tidak hanya dibebankan kepada para pendakwah, melainkan kewajiban seluruh umat. Diantara keseluruhan yang dimaksud adalah adanya peran serta antara Pemimpin dan Ulama. Pemimpin merupakan seseorang yang diberi kuasa dalam menata dan mengatur kehidupan bermasyarakat sesuai dengan aturan dan undangundang yang ada, sedangkan para ulama adalah sosok yang hadir di tengah masyarakat sebagai penuntun dan penerang dalam mengamalkan aspek-aspek ajaran agama yang telah diperintahkan oleh Allah swt dan Rasul-Nya. Dalam penelitian ini, penulis akan mengungkapkan dan menjawab tiga pertanyaan penelitian, yaitu: 1) term kepemimpinan dalam Islam, 2) dakwah amanah allah bagi para ulama, 3) kolaborasi ulama dan umara dalam berdakwah.
\end{abstract}

\section{Kata Kunci: Kolaborasi Dakwah, Ulama dan Umara}

\section{PENDAHULUAN}

Dakwah pada dasarnya adalah mengajak umat manusia kepada kebaikan. Adapun sumber kebaikan yakni al-qur'an, hadis dan sebagainya. Jika merujuk pada surat an-Nahl ayat 125 materi dakwah sangat tidak terbatas, yang membatasinya adalah perbuatan itu baik atau tidak, jika sebuah perbuatan itu baik yang membawa manusia taat kepada Allah, maka itulah materi dakwah. 
Dengan tidak adanya batasan terhadap materi dakwah, maka pelaku dakwah (da'i) juga tidak terbatas pada para ahli di bidang ilmu agama saja, tetapi seluruh umat Islam. Manusia bisa berdakwah sesuai dengan keahlian dan keterampilannya masing-masing. Misalnya orang yang memiliki keahlian di bidang ilmu lingkungan, materi dakwahnya bisa berupa ajakan untuk menjaga lingkungan, seperti tidak membuang sampah sembarangan, tidak menebang pohon atau tidak membuka tambang galian c secara ilegal karena akan berdampak buruk kepada lingkungan.

Namun ruang lingkup dakwah yang dilakukan ahli lingkungan hanya sebatas menyampaikan dan mengajak masyarakat untuk melestarikan lingkungan, sampai disini da’i tidak bisa mengambil tindakan jika terjadi pelanggaran/perusakan lingkungan oleh masyarakat.

Di sinilah letak pentingnya pemerintah dalam berdakwah, karena pemerintah memiliki otoritas dalam mencegah kemungkaran dengan cara membuat peraturan tentang sanksi bagi masyarakat yang merusak lingkungan. Dengan demikian, dakwah diharapkan jadi lebih efektif. Atas dasar hal itu, penelitian ini mencoba mendudukkan kembali peran pemerintah dalam kegiatan dakwah.

\section{HASIL DAN PEMBAHASAN}

\section{Kepemimpinan dalam Islam}

Dalam al-Quran telah dijelaskan bahwa manusia adalah makhluk yang telah diamanahkan oleh Allah swt sebagai pemimpin di muka bumi. Tugas pemimpin adalah yang dapat memberikan kenyamanan bagi umat di mana saja ia berada. Seperti disebutkan dalam firmanNya:

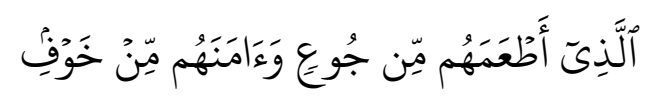

Maksudnya: "Yang telah memberi makanan kepada mereka untuk menghilangkan lapar dan mengamankan mereka dari ketakutan.” (QS. Al-Qurays : 4). 
Manusia pada dasarnya diciptakan oleh Allah swt di bumi ini sebagai pemimpin (khalifah), sebagai seorang pemimpin baik secara individu maupun secara kolektif kepemimpin seseorang akan dimintai pertanggungjawabannya. Oleh karena itu manusia sebelum ia muncul dan diberikan amanah untuk orang lain, hendaknya ia harus bisa memimpin dirinya sendiri.

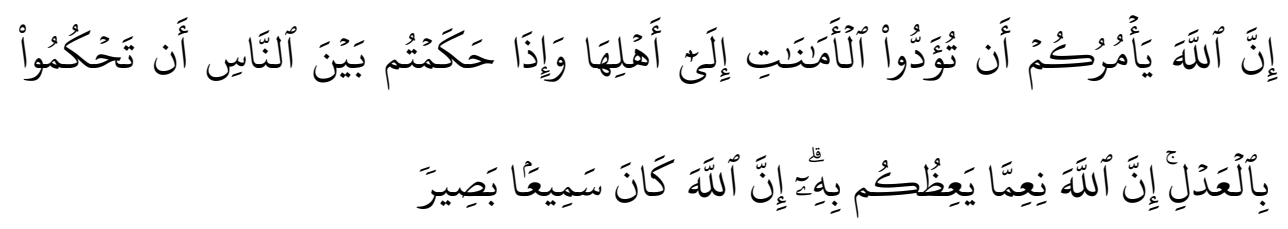

Maksudnya: "Sesungguhnya Allah menyuruh kamu menyampaikan amanat kepada yang berhak menerimanya, dan (menyuruh kamu) apabila menetapkan hukum di antara manusia supaya kamu menetapkan dengan adil. Sesungguhnya Allah memberi pengajaran yang sebaik-baiknya kepadamu. Sesungguhnya Allah adalah Maha Mendengar lagi Maha Melihat."(QS. AnNisa' 58).

Amanah merupakan suatu titipan yang dipertanggungjawabkan oleh individu kepada seseorang, dengan berbagai bentuk baik terhadap Allah atau kepada hamba, dengan jenis perbuatan dalam bentuk pekerjaan, ucapan atau kepercayaan hati. Wujud dari tanggung jawab yang mesti dilakukan oleh masing-masing individu. Jika tugas tersebut diabaikan atau dipandang remeh sehingga lalu disisi Allah swt hal ini merupakan suatu kesalahan, sehingga mereka berhak menerima balasan dari Tuhan yakni diberi ganjaran pahala bagi yang menunaikannya dan diberi siksa bila mereka mengabaikannya (AlGhazali, 1996, h. 122). Sebagaimana dijelaskan dalam Kamus Bahasa Melayu, pemimpin adalah orang yang memimpin dan kepemimpinan adalah keupayaan (kebolehan, kecekapan dsb) sebagai pemimpin (Kementerian Pendidikan Malaysia, 1994, h. 1038). Sedangkan kepemimpinan dapat diartikan sebagai usaha untuk meyakinkan dan mempengaruhi orang perorang atau sekumpulan individu untuk melaksanakan sesuatu tugas serta mencapai sesuatu tujuan/matlamat serta dapat memberi kepuasan kepada 
orang-orang yang dipimpin (Othman, 1990, h. 99). Apa yang dijelaskan dari definisi ini adalah kepemimpinan merupakan aspek utama yang mempengaruhi tindak tanduk manusia untuk melakukan suatu tugas. Definisi ini perlu diberi perhatian karena ia membedakan seorang pemimpin dengan seorang pemerintah (commander). Seorang pemerintah hanya menekankan pengarahan. Persoalan penerimaan oleh pengikutnya tidak menjadi persoalan penting karena seorang pemerintah layaknya mempunyai kekuasaan menghukum (Othman, 1990, h. 99).

Allah swt mengingatkan kepada manusia, tentang syarat atau kriteria pemimpin yang amanah dalam firmannya:

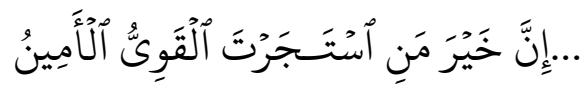

Maksudnya: ".....karena sesungguhnya orang yang paling baik yang kamu ambil untuk bekerja (pada kita) ialah orang yang kuat lagi dapat dipercaya."(QS. Al-Qasas : 26).

Jelas bahwa dalam ayat tersebut Allah swt menyebutkan kriteria pemimpin yaitu; quwwah maksudnya adalah kesanggupan dan kemampuan untuk melakukan tugas yang diamanahkan. Seorang pemimpin juga menyadari bahwa ketika agamanya dihina, direndahkan bahkan dikekang perjalanan menyebarkan ajaran Islam jangan kepada umat manusia secara universal, untuk internal sesama umat saja dibatasi. Seakan-akan dakwah Islam dewasa ini tidak ada satu tempatpun yang memberikan kebebasan kepada seorang muslim untuk menyampaikan totalitas Islam dengan terangterangan. Urusan kaum muslimin tidak akan terselesaikan dengan tuntas kecuali dari masing-masing dari mereka menyadari bahwa dirinya adalah bagian dari keseluruhan kaum muslimin (Hawwa, 1988, h. 242).

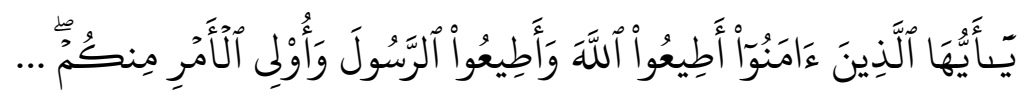


Maksudnya: "Hai orang-orang yang beriman, taatilah Allah dan taatilah Rasul (Nya), dan ulil amri di antara kamu..."(QS. An-Nisa': 59).

Ibnu Abbas menafsirkan kata Ulil Amri sebagai ulama dan fuqaha. Umara dalam sistem Islam diambil dari fuqaha, sebagaimana dikatakan Umar bin Khatab; Menjadi faqihlah sebelum kamu diangkat menjadi penguasa (Hawwa, 1988, h. 167). Jelaslah bahwa pemimpin sebenarnya orang yang melakukan kebaikan dan kemaslahatan yang dipimpinnya.

Sabda Nabi Muhammad saw:

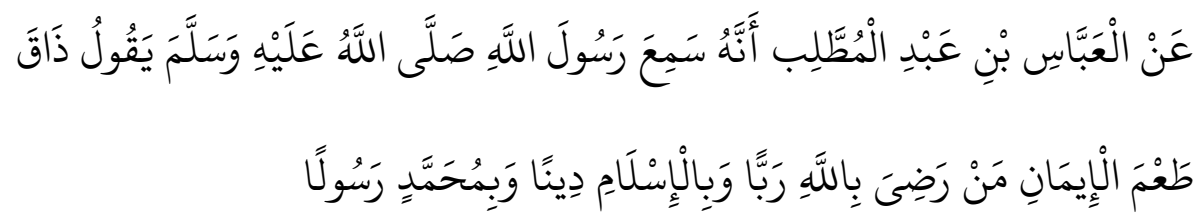

Maksudnya: "Dari al-Abbas bin Abdul Muththalib bahwa dia mendengar Rasulullah shallallahu 'alaihi wasallam bersabda: "Telah merasakan nikmatnya iman bagi orang yang ridla dengan Allah sebagai Rabb dan Islam sebagai agama serta Muhammad sebagai Rasul." (HR. Muslim).

Pemimpin yang beriman adalah pemimpin yang mengajak masyarakatnya tunduk dan taat akan Allah swt serta Muhammad saw sebagai Rasulnya. Seperti yang digambarkan oleh Nabi Muhammad saw dalam hadis diatas, tentu umat Islam harus berhati-hati dan selektif dalam menentukan siapa yang layak dan pantas yang menjadi ikutan dalam kehidupan bermasyarakat. Kekuasaan yang dimiliki dan disandang oleh manusia di dunianya hanyalah kekuasaan sementara. Sedangkan kekuasaan yang hakiki adalah kekuasaan Allah swt. Allah telah memberikan contoh kepada umat Muhammad saw bahwa mereka yang angkuh dan sombong dengan amanah yang dititipkan sebagai pemimpin, maka mereka akan merasakan siksaan dari Allah swt zat yang Maha Kuat dan Maha Kuasa dan berkehendak atas segalagalanya, firmannya: 


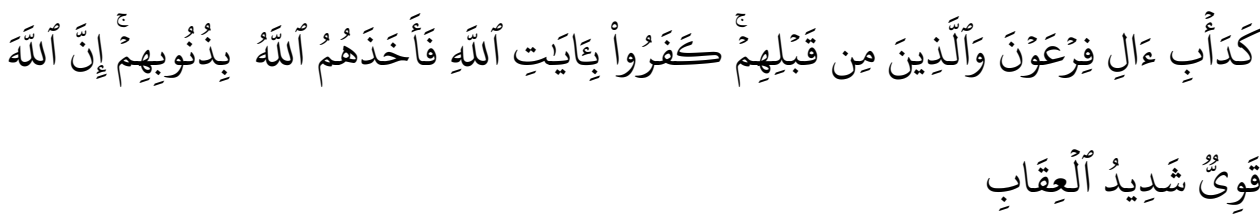

Maksudnya: "(keadaan mereka) serupa dengan keadaan Fir'aun dan pengikut-pengikutnya serta orang-orang yang sebelumnya. Mereka mengingkari ayat-ayat Allah, maka Allah menyiksa mereka disebabkan dosa-dosanya. Sesungguhnya Allah Maha Kuat lagi amat keras siksaan-Nya." (QS. Al-Anfal : 52).

Menurut al-Maraghi, berkaitan dengan ayat tersebut adalah bahwa sesungguhnya Allah swt tidak akan membedakan sebagian bangsa dan umat karena keturunan dan kelebihan sebagian nenek moyangnya atas yang lain, bahkan pada tingkat kenabian atau yang lebih rendah daripada itu, kemudian Allah mengamanahkan kepada mereka kekuasaan sehingga dapat melaksanakaan tugasnya sebagai khalifah, perlu dijelaskan bahwa para nabi yang menjadi nenek moyang mereka lalu mereka menjadi sombong dan lupa diri. Seperti keadaan Bani Israil yang tertipu oleh kepanatikannya kepada nenek moyangnya dan merasa lebih mulia atas seluruh bangsa karena keturunannya itu (Ahmad, 1987, h. 24). Demikian pula dengan golongan Nasrani dan Islam sesudah itu. Mereka mengikuti budaya dan adat istiadat golongan Yahudi dan terpedaya oleh agamanya, padahal sesungguhnya mereka sendiri merupakan kaum yang paling menentangnya.

Sesungguhnya Allah swt adalah Tuhan yang Maha Mendengar apa yang disampaikan oleh kelompok pendusta terhadap Rasul dan Allah adalah Tuhan yang Maha Mengetahui apa yang dikerjakan oleh manusia serta segala bentuk perbuataannya baik secara nyata atau tersembunyi. Dia Allah akan memberikan balasan terhadap mereka dengan kelakuan sebagaimana yang mereka katakan dan perbuat, lalu juga membalas yang baik dengan kebaikan dan perbuatan yang buruk dibalas dengan keburukan pula. 
Generasi milenial sebagai estafet pemimpin masa depan hendaknya mengetahui bahwa pintu kemaksiatan dan kezaliman tidak akan tertutup, selama manusia tidak yakin, jauh di atas dirinya ada kekuatan lain yang Maha Besar, yang akan mengusut dan meminta segala pertanggungjawaban dari semua tindak tanduknya. Dan kekuatan itulah yang akan memberikan hukum dan ganjarannya. Menurut Al-Maududi, manusia yang kecil dan lemah tidak akan mampu menciptakan aturan yang sempurna, yang dapat menciptakan keadilan dan kebahagiaan. Seseorang atau sekelompok manusia jika memiliki kekuatan yang tiada terbatas, maka dia akan lebih sewenang-wenang, sombong, tidak terkendali dan malah akan mengangkat diri seperti Fir'aun yang terbesar di muka bumi, mengankat si A, menjatuhkan si B dan akhirnya mengangkat dan mengaku tuhan, yang menguasai seluruh alam semesta (Abul, 1991, h. 56-57).

Pada prinsipnya ajaran Islam mendidik umatnya supaya selalu menunaikan amanah yang telah diberikan, mereka tidak mengabaikan tanggung jawab tersebut dalam segala hal dan pada semua sesuai dengan kesanggupan. Karena bertanggung jawab adalah suatu aspek penting, bahkan yang menjadi kriteria bagi seseorang dalam mengukur dan melihat usaha dan amalnya, bahkan juga dapat menjadi tolak ukur akan kesuksesan berhasilnya bangsa dalam mempertahankan kesinambungan hidupnya (Al-Ghazali, 1996, h. 124). Allah swt telah menjadikan amanah itu salah satu karakter dan sifat hamba-Nya yang saleh.

Firman-Nya:

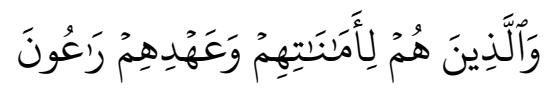

Maksudnya: "Dan orang-orang yang memelihara amanat-amanat (yang dipikulnya) dan janjinya."(QS. Al-Mukminun : 8).

Kedudukan umara atau pemimpin dalam Islam adalah mereka yang senantiasa menjaga kewibawaan agamanya, akhlaknya dan juga pengabdian 
untuk bangsanya. Karena dengan kesadaran itu, ia mengetahui bahwa sekecil apapun yang diperbuatnya pasti ada resiko baik bagi dirinya sendiri dan juga rakyatnya, apalagi disisi Allah swt.

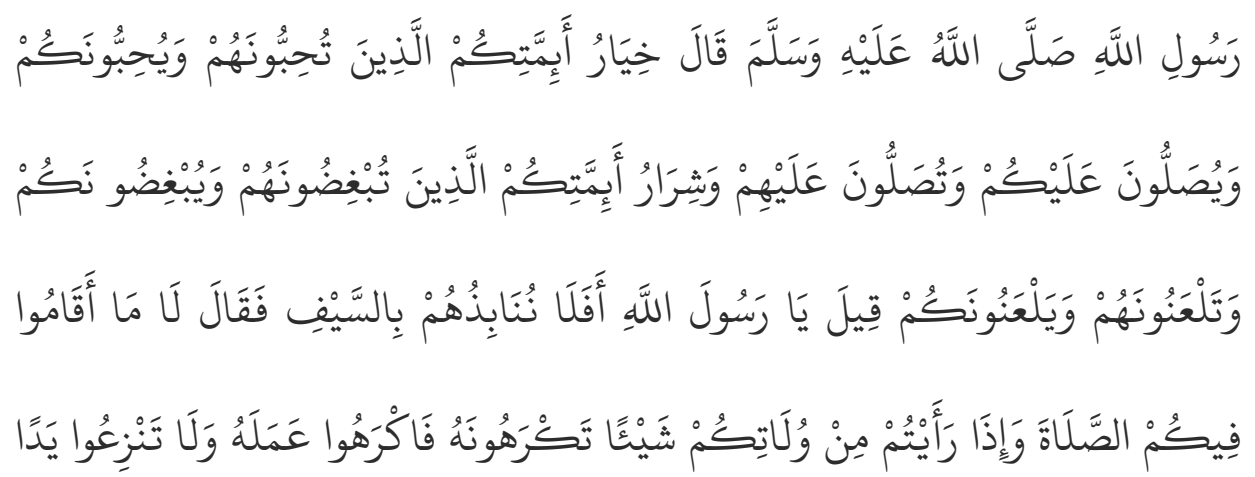

مِنْ طَاعَةِ

Maksudnya: "Rasulullah shallallahu 'alaihi wasallam, beliau bersabda: "Sebaik-baik pemimpin kalian adalah mereka mencintai kalian dan kalian mencintai mereka, mereka mendo'akan kalian dan kalian mendo'akan mereka. Dan sejelek-jelek pemimpin kalian adalah mereka yang membenci kalian dan kalian membenci mereka, mereka mengutuk kalian dan kalian mengutuk mereka." Beliau ditanya, "Wahai Rasulullah, tidakkah kita memerangi mereka?" maka beliau bersabda: "Tidak ,selagi mereka mendirikan shalat bersama kalian. Jika kalian melihat dari pemimpin kalian sesuatu yang tidak baik maka bencilah tindakannya, dan janganlah kalian melepas dari ketaatan kepada mereka." (HR. Muslim).

Dalam ajaran Islam yang mulia sebagaimana disebutkan dalam sabda Nabi Muhamad saw yang selalu mengajarkan umat ini memelihara akhlak dan bersikap santun terhadap pemimpinnya. Meskipun seorang pemimpin itu berbuat zalim dan tidak berlaku adil, kepada rakyat, namun rasa marah dan benci itu hanya pada perbuatannya.

Demikian pula dalam al-Quran Allah swt juga menjelaskan bahwa resiko dari perbuatan seseorang tidak dipikul oleh orang lain. 


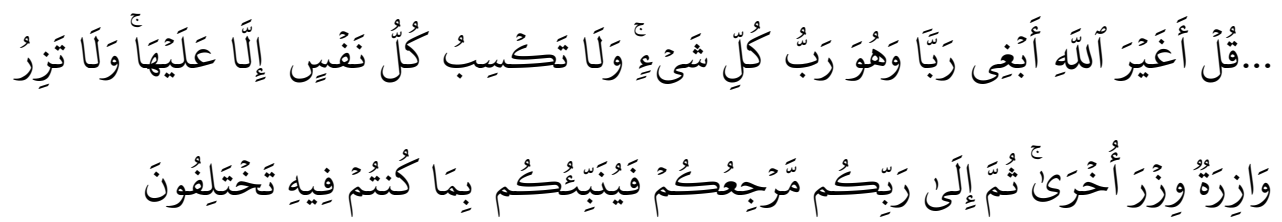

Maksudnya: "....Dan tidaklah seorang membuat dosa melainkan kemudharatannya kembali kepada dirinya sendiri; dan seorang yang berdosa tidak akan memikul dosa orang lain. Kemudian kepada Tuhanmulah kamu kembali, dan akan diberitakan-Nya kepadamu apa yang kamu perselisihkan.”(QS. Al-An'am : 164).

Selanjutnya dijelaskan kembali dalam surat lain:

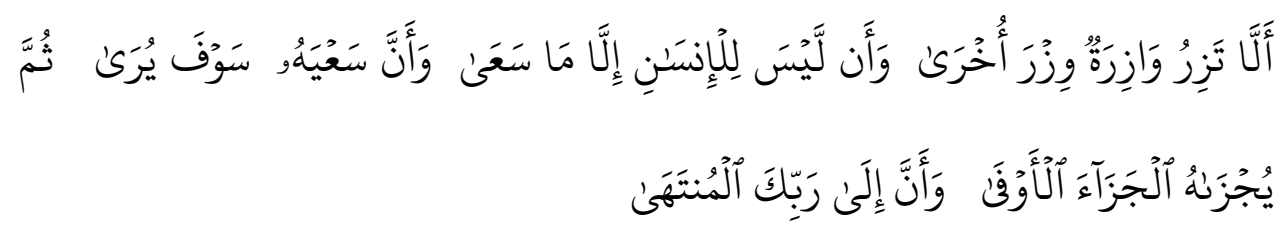

Maksudnya: "(Yaitu) bahwasanya seorang yang berdosa tidak akan memikul dosa orang lain-dan bahwasanya seorang manusia tiada memperoleh selain apa yang telah diusahakannya-dan bahwasanya usaha itu kelak akan diperlihatkan (kepadanya)Kemudian akan diberi balasan kepadanya dengan balasan yang paling sempurna-dan bahwasanya kepada Tuhanmulah kesudahan (segala sesuatu).”(QS. An-Najm : 38-42).

Umat Islam dan pendakwah jangan sampai puas dan bosan mengingatkan umat, apalagi seorang pemimpin yang diberikan kekuasaan, sangat berkesempatan menyadarkan masyarakatnya terutama pegawaipegawainya dari semua lembaga dan kementerian, bahwa Allah swt tidak pernah tidur dan lengah dari pekerjaan hambanya, bila berbuat dosa maka dosa itu menimpa dirinya demikian pula sebaliknya.

\section{Dakwah Amanah Allah Bagi Para Ulama}

Sebagai amanah terhadap para ulama dakwah Islamiyah merupakan kewajiban bagi mereka yang telah dilebihkan oleh Allah orang mempunyai kemampuan dan ilmu serta keahlian dalam berdakwah. Menyeru manusia ke 
jalan Allah secara perorangan maupun kolektif dari kalangan ulama juga harus memerlukan kepakaran, yang bukan hanya keberaniannya saja, akan tetapi merangkum segala hal yang dapat membantu tercapainya misi ajaran Islam tersebut. Karena ulama adalah orang-orang yang terpandang dan mereka takut melakukan kekeliruan apalagi memiliki unsur kesengajaan, tentunya ketakutan itu ditujukan kepada Allah swt.

Firman Allah swt:

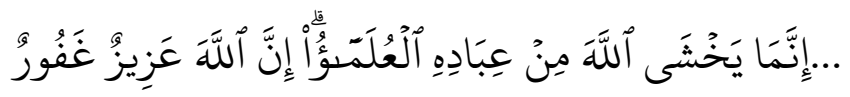

Maksudnya: "....Sesungguhnya yang takut kepada Allah di antara hambahamba-Nya, hanyalah ulama. Sesungguhnya Allah Maha Perkasa lagi Maha Pengampun.”(QS. Fathir : 28).

Pentingnya kiprah ulama dalam berdakwah karena hidup berjamaah tanpa didampingi oleh orang yang 'alim, maka ibadah secara berjamaah hanya sebatas melaksanakan kewajiban rutinitas tanpa pengetahuan yang jelas, apalagi umat telah mengetahui bahwa ibadah yang dikerjakan secara berjamaah umpamanya lebih baik daripada sendiri-sendiri. Tentu tidak cukup umat ini sekedar memiliki ilmu tentang berjamaah saja.

Sebagai seorang ulama tentunya mampu mengajarkan umat ini untuk merasakan bagaimana nikmat dan indahnya ajaran Islam dalam menjalani hidup dan kehidupan. Cara untuk menikmati indah dan bahagia dalam Islam bisa dilakukan dengan, menyendiri (berkhalwat) kepada Allah setiap saat. Seorang ulama juga mampu menanamkan kepada umat ini, agar bisa menegakkan Islam dalam hatinya masing-masing dan juga mencintai Islam sepenuhnya.

Pencapaian dakwah ini akan membangun komitmen umat agar senantiasa berjuang bersama ulama, sehingga seorang muslim dan muslimat memiliki pandangan melangkah dan menatap jauh ke depan bahwa ia akan menuju suatu tempat yang telah dijanjikan oleh Allah swt dan Rasulnya di 
akhirat kelak yakni surga-Nya. Meskipun dakwah dapat dilaksanakan secara sendirian dan dapat dianggap lebih mudah, namun perlu diketahui bahwa dakwah yang dilaksanakan secara kolektif atau terorganisir akan terasa lebih indah.

Membicarakan soal amal, sesungguhnya Allah swt telah menjelaskan bahwa dapat dikerjakan secara sendiri atau berjamaah. Sesuai dengan tingkat iman dan kesanggupan masing-masing. Karenanya Allah swt menjelaskan daalam firmanNya:

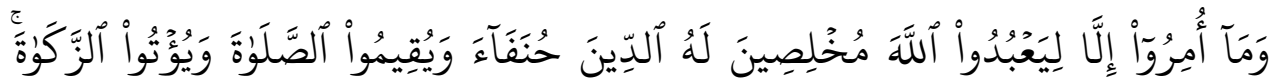

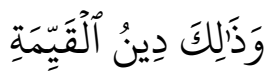

Maksudnya: "Padahal mereka tidak disuruh kecuali supaya menyembah Allah dengan memurnikan ketaatan kepada-Nya dalam (menjalankan) agama yang lurus, dan supaya mereka mendirikan shalat dan menunaikan zakat; dan yang demikian itulah agama yang lurus.”(QS. Al-Bayyinah : 5).

Pada ayat di atas dapat dipahami bahwa mengerjakan ibadah kepada Allah swt hendaknya dengan keikhlasan dan ketulusan, sehingga ibadah tersebut benar-benar murni karena Allah. Bukan karena siapa-siapa, bukan karena ingin mendapat pujian dan penghargaan dari manusia.

Firmannya lagi menyebutkan:

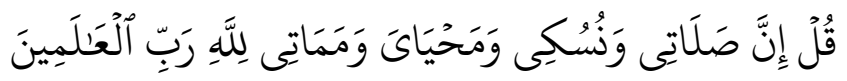

Maksudnya: "Katakanlah: sesungguhnya sembahyangku, ibadatku, hidupku dan matiku hanyalah untuk Allah, Tuhan semesta alam"(QS. Al-An'am : 162).

Keluasan ilmu, memiliki teknik dan strategi serta pengaruh dalam masyarakat dan umat hal seperti ini sangat mendukung keberhasilan dakwah. Apalagi menghadapi ancaman dari kelompok manusia yang memusuhi Islam sebagai agama rahmatan lil'alamin, penjelasannya haruslah pendakwah yang 
berkomitmen dengan Allah dan Rasul. Karena di akhir zaman ini bila merujuk dengan hadis nabi banyak sekali ulama-ulama yang menggadaikan agamanya demi kepentingan duniawi. Sekedar berebut mendapat pengaruh dan penghormatan, sehingga lupa dengan amanah yang Allah berikan kepada mereka.

Nabi saw besabda:

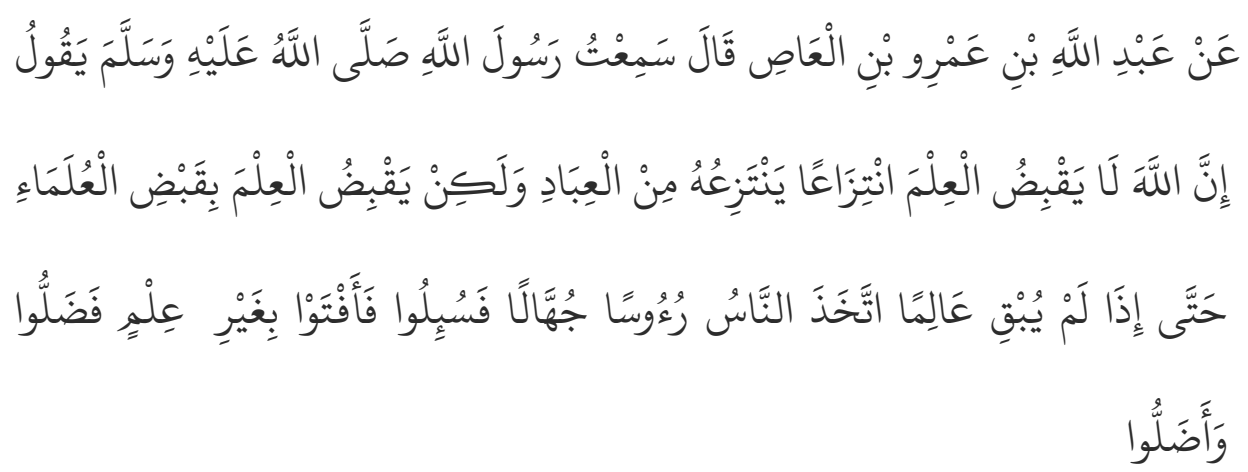

Maksudnya: "Dari Abdullah bin 'Amru bin 'Ash berkata: aku mendengar Rasulullah shallallahu 'alaihi wasallam bersabda: "Sesungguhnya Allah tidaklah mencabut ilmu sekaligus mencabutnya dari hamba, akan tetapi Allah mencabut ilmu dengan cara mewafatkan para ulama hingga bila sudah tidak tersisa ulama maka manusia akan mengangkat pemimpin dari kalangan orang-orang bodoh, ketika mereka ditanya mereka berfatwa tanpa ilmu, mereka sesat dan menyesatkan." (HR. Muslim).

Ulama sebagai tonggak dan sosok yang idealnya sebagai contoh dan ikutan bagi umat, suara kebenaran dan keteguhan membela yang hak semestinya ada dalam kekuasaan ulama. Namun harapan tersebut selalu mengecewakan dikarenakan oleh adanya oknum-oknum yang berpura-pura tidak tahu bahkan tidak mau tahu dengan situasi umat yang menunggu konsistensi ulama dalam menyampaikan misi dakwah Islamiyah.

Inilah sekilas gambaran dari sabda nabi Muhammad saw di atas, bahwa wafat atau matinya ulama maksudnya adalah tidak bersuaranya ketika agama ini dilecehkan, direndahkan ataupun dalam bahasa kini adanya 
penistaan dengan berbagai macam bentuk. Padahal eksistensi ulama dalam kehidupan berbangsa dan bernegara adalah sebagai warasatul anbiya'. Dalam pandangan Hamdan Rasyid sebagaimana dijelaskan, ulama adalah mereka yang mempunyai ilmu pengetahuan tentang ayat-ayat Allah, baik ayat-ayat yang bersifat kauniyyah maupun qur'aniyya yang dengan pengetahuan tersebut mereka semakin mengagumi kekuasaan dan keagungan-Nya yang pada akhirnya mengantarkan mereka pada sikap khasyatullah, takut kepada Allah (Rasyid, 2007, h. 19).

Apalagi ketika melihat betapa banyak dan ramainya lulusan agama seperti pondok pesantren dan bahkan dari berbagai Perguruan Tinggi Islam antaralain; Universitas Islam Negeri (UIN), Institut Agama Islam Negeri (IAIN), Sekolah Tinggi Agama Islam Negeri (STAIN) dan juga Perguruan Tinggi Islam Suwasta lainnya. Begitu bahagia melihatnya, karena dari waktu ke waktu dan zaman ke zaman senantiasa generasi yang meneruskan perjuangan dakwah Islamiyah. Namun yang betul-betul yang berminat dan interes untuk menjadi seorang ulama yang akan langsung membimbing ummat, sudah semakin berkurang (Yunan Nasution, 1988, h. 59). Demikian juga halnya sebagian besar lulusan-lulusan pesantren itu. Lebih-lebih setelah dalam pesantren-pesantren itu diajarkan berbagai pengetahuan keterampilan dengan asumsi supaya mereka dapat berdikari mencari nafkah dalam masyarakat, maka semakin berkurang pengkhususan tentang pengetahuanpengetahuan agama, yang dengan sendirinya berkurang pula calon-calon yang akan menjadi Ulama (Yunan Nasution, 1988, h. 60).

Agar umat Islam tidak salah dalam melaksanakan tatanan kehidupan, maka perlu struktur masyarakat yang dinamai dengan pemimpin ataupun imam. Karena hidup berjamaah tanpa dibangun struktur yang hebat dan kuat tentu akan mudah rusak dan roboh.. Dalam Islam hidup berjamaah bagaikan mendirikan sebuah bangunan sebuah bangunan, bila ingin bangunan itu kuat maka perlu diperhatikan pondasinya, letak bangunannya dan siapa yang 
membangun/tukangnya dan sebagainya sehingga bangunan yang didirikan tersebut benar-benar kuat dan kokoh, inilah hakikat dari keberadaan Ulama. Mereka tahu mana urusan yang prinsip dan yang harus, dan juga hal-hal yang memudahkan bagi umat, sehingga tidak terasa oleh umat ini ada pemaksaan atau mempersulit hidup dalam mengamalkan ajaran agama tersebut.

M. Natsir mengemukakan bahwa ulama bukanlah sesorang yang dapat disamakan dengan pemilihan pemimpin seperti pemilihan legislatif dan eksekutif atau pilkada serta yang seumpamanya dengan suara pilihan terbanyak, ulama juga bukan yang diangkat oleh persidangan kongres. Akan tetapi kehadirannya tumbuh dari dalam hati umat di mana mereka hidup dan tinggal. Dengan itu keberadaan ulama jauh lebih teguh dan suci dari pemimpin pergerakan yang dipimpin organisasi atau pejabat pemerintah (Natsir, 1973, h. 163). Dijelaskan lagi bahwa ulama ialah pewaris nabi, pemuka umat yang mendapat pengakuan agama. Dalam mencapai kemajuan rakyat umumnya, kiprah ulama yang berada di suatu daerah itu hendaknya mendapat tempat yang terhormat, karena seperti yang diketahui bahwa mereka adalah warasatun anbiya'.

Pemerintah setempat semestinya ikut memfasilitasi perjuangan ulama dalam menyiarkan ajaran Islam. Dengan adanya dukungan dan keikutsertaan pemerintah setempat maka akan terlaksana misi dakwah Islam yang dilakukan oleh para pendakwah melalui kegiataan keulamaan tersebut. Inilah satu harapan yang besar dari umat dalam melaksanakan aktifitas dakwah melalui berbagai lembaga dan organisasi Islam yang ada. Koordinasi pekerjaan antara ulama-ulama, pegawai-pegawai pemerintah dan pemuka-pemuka pergerakan sosial atau politik, tidak akan diperdapat, bila mana pihak ulama tidak turut memperhatikan dan menurutkan gelora zaman (Natsir, 1973, h. 164).

Tentu khazanah intelektual atau wawasan seorang ulama yang dapat membedakan mana urusan yang mudah bagi masyarakatnya dalam 
mengamalkan dan dipelajari dan hal-hal yang sulit yang tidak harus dipaksakan dengan pertimbangan kemampuan dan kesanggupannya, demikian pula tentang kabar gembira dan berita ancaman yang perlu disampaikan pada situasi dan kondisi yang sesuai.

$$
\begin{aligned}
& \text { عَنْ سَعِيدِ بْنِ أَبِى بُرْدَة عَنْ أَبِيهِ عَنْ جَدِّهِ قَالَ لَمَّا بَعَثَهُ رَسُولُ اللَّهِ صَلَّى اللَّهُ عَلَيْهِ }
\end{aligned}
$$

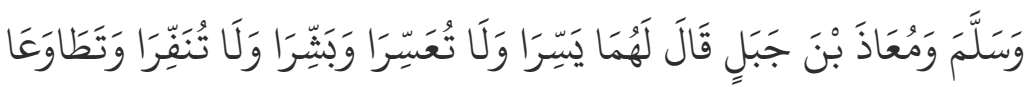

Maksudnya: "Dari Sa'id bin Abu Burdah dari Ayahnya dari Kakeknya dia berkata: "Ketika beliau mengutusnya bersama Mu'adz bin Jabal, beliau bersabda kepada keduanya: "Mudahkanlah setiap urusan dan janganlah kamu mempersulit, berilah kabar gembira dan jangan kamu membuatnya lari, dan bersatu padulah!” (HR. Bukhari).

Ulama adalah barisan terdepan yang menjawab tantangan dan problema umat, ulama adalah individu masyarakat yang dianggap terpandang, karenanya seperangkat atribut keulamaan tersebut mestilah dihibahkan untuk kepentingan agama Allah. Bukan sebagai sosok yang terjebak memprovokasi umat hingga terpecah belah yang dikarenakan oleh kepentingan kedudukan dan pengaruh serta jabatan yang akan mungkin diperolehinya. Jadilah Ulama yang benar-benar memegang amanah untuk menegakkan agama sebagaimana tujuan amanah yang diberikan oleh Allah swt kepadanya.

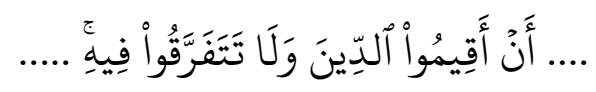

Maksudnya: "...Tegakkanlah agama dan janganlah kamu berpecah...”(QS. Asy-Syura : 13)

Dengan demikian sangatlah jelas bahwa Ulama merupakan pelaksana untuk menegakkan kelangsungan hidup beragama yang mesti ditegakkan. Agar manusia merdeka menghambakan dirinya kepada Allah swt, dan juga 
ulama adalah orang yang diberikan mandat membimbing, menuntun dan mendidik umat.

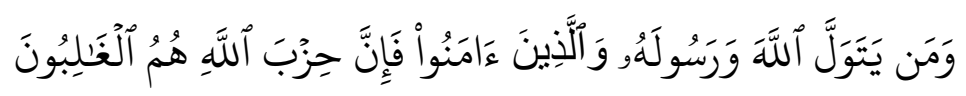

Maksudnya :'Dan barangsiapa mengambil Allah, Rasul-Nya dan orangorang yang beriman menjadi penolongnya, maka sesungguhnya pengikut (agama) Allah itulah yang pasti menang"'(QS. Al-Maidah : 56)

Firmannya lagi :

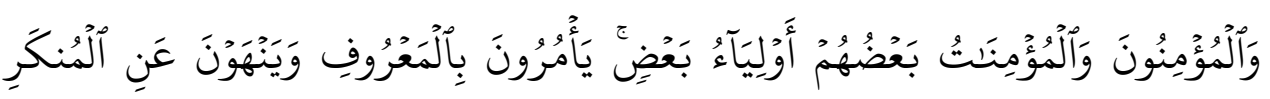

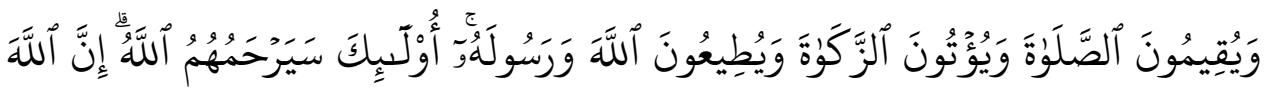

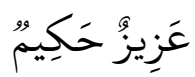

Maksudnya: "Dan orang-orang yang beriman, lelaki dan perempuan, sebahagian mereka (adalah) menjadi penolong bagi sebahagian yang lain. Mereka menyuruh (mengerjakan) yang ma'ruf, mencegah dari yang munkar, mendirikan shalat, menunaikan zakat dan mereka taat pada Allah dan Rasul-Nya. Mereka itu akan diberi rahmat oleh Allah; sesungguhnya Allah Maha Perkasa lagi Maha Bijaksana.’(QS. At-Taubah : 71)

Dengan memiliki keunggulan, kelebihan dan kehormatan dari umat atau masyarakat, ulama juga diuji oleh Allah swt. Ujian tersebut adakalanya dalam bentuk kebaikan dan adapula dengan kejahatan. Tak lebih kurang dengan orang mukmin yang lain, tapi disisi lain ujian dimaksud adalah untuk membedakan antara yang mujahid dan yang sabar dari kalangan mereka.

Firman-Nya:

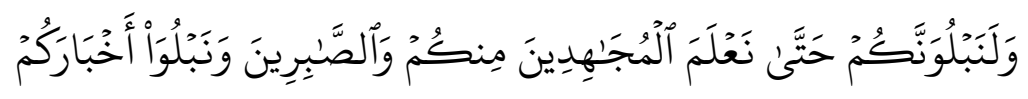

Maksudnya: "Dan sesungguhnya Kami benar-benar akan menguji kamu agar Kami mengetahui orang-orang yang berjihad dan 
bersabar di antara kamu, dan agar Kami menyatakan (baik buruknya) hal ihwalmu."(QS. Muhammad : 31)

Teranglah bagi umat bahwa ujian itu bukan hanya berlaku kepada masyarakat awam saja, tetapi malah ujian terkadang lebih berat terhadap para ulama, tantangan dan ujian tersebut yang terberat adalah ketika behadap dengan hawa nafsu dunia dan syaitan. Di samping kewajiban dan tanggung jawab yang diamanahkan kepada mereka. Sebagai muslim yang integritasnya telah teruji, niscaya mereka selalu memberikan dukungan dan pertolongan dalam menegakkan agama Allah yang secara khusus dilaksanakan oleh para ulama, kemudian secara universal kerja dakwah ini mulai dari masing-masing individu. Inilah bentuk istiqomahnya kaum muslimin, mereka hanya menjadikan Allah swt dan Rasul-Nya Muhammad saw yang pantas dijadikan penolong dan juga mereka yang berjuang menegakkan agama Allah yakni mereka pendakwah, pemimpin dan ulama-ulama yang senantiasa dalam keadaan beriman.

\section{Kolaborasi Ulama dan Umara dalam Berdakwah}

Perlu dijelaskan bahwa dakwah dengan kekuasaan, adalah merupakan aspek paling utama tingkatannya. Karena peran umara (pemerintah) dalam menegakkan amar makruf nahi mungkar melebihi keberadaan dan wewenang orang lain. Memandang tanggung jawab dan tugas penting ini pemerintah dan dan ulama mestilah mampu membangun kerja sama dalam melaksanakan tugas dakwah. Umara dan ulama ini mestinya bersinergi. Antara satu sama lain harus bekerja sama dan tidak terpisahkan. Pemerintah dan Ulama bila telah terjalin saling memahami dan mereka dapat membentuk kerja samanya dengan baik tentu segala persoalan-persoalan umat akan teratasi.

Ajaran Islam hendaknya jangan sampai hilang keberadaannya di muka bumi ini, bila masing-masing individu muslim menjaga dan memelihara eksistensi dan esensinya Islam tersebut. Karena dapat diketahui bahwa dengan kemajuan dan perkembangan ilmu pengetahuan dan teknologi tanpa 
disadari akan menguras waktu dan kesempatan umat memperdalam ilmu keislaman, sehingga muncul pemikiran baru yang tidak peduli dengan tuntunan agama, akibat dari pada perilaku yang demikian turut hilang karakteristik muslim itu sendiri. Maka kepribadian umat akan menjadi merosot dan akhlaknyapun menjadi buruk, bila hal ini segera dilakukan bimbingan dan pendidikan tentu mereka akan kembali kepada akhlak dan perilaku yang baik sebagaimana kepribadian yang pernah dibina dan di bentuk oleh Rasulullah saw dan telah ditentukan kriterianya oleh al-Quran yang diserukan melalui ayat-ayatnya (Amin Abdul Azizi, 2000, h. 72).

Umara dan Ulama merupakan salah satu yang memiliki peranan penting dalam usaha penyebaran dan menyerukan agama Allah swt.

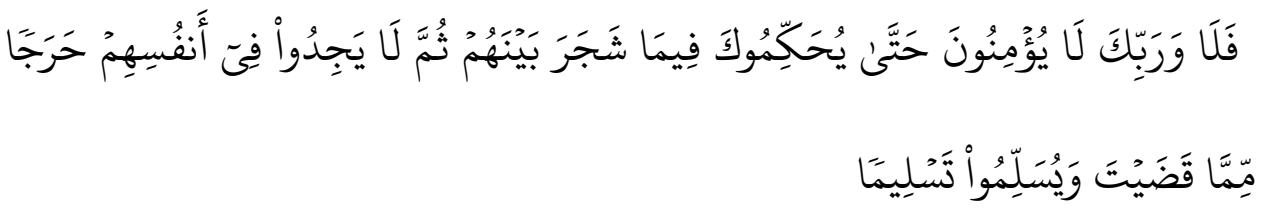

Maksudnya: "Maka demi Tuhanmu, mereka (pada hakekatnya) tidak beriman hingga mereka menjadikan kamu hakim terhadap perkara yang mereka perselisihkan, kemudian mereka tidak merasa dalam hati mereka sesuatu keberatan terhadap putusan yang kamu berikan, dan mereka menerima dengan sepenuhnya."(QS. An-Nisa : 65)

Pada dasarnya dakwah yang dituntun Nabi Muhammad SAW dalam sabdanya menjelaskan bahwa ada tiga bentuk, yaitu dengan tangan (kekuasaan), lisan, dan hati. Dari bentuk yang dijelaskan oleh Rasulullah saw memberikan ilustrasi bagi umat ini bahwa, peran pemerintah menjadi prioritas utama yang mesti wujud dan hadir mendakwahi rakyatnya. Para ulama dan da'i yang berdakwah melalui lisan tingkatannya masih di bawah pemerintah (umara). Tentu sudah semestinya pemerintah memperhatikan soal keperluan dan kebutuhan dalam bentuk pendanaan ormas-ormas dakwah dan para muballigh yang menjalankan tugas dakwah tersebut. 
Eksistensi pendakwah sesungguhnya telah membantu peran pemerintah untuk menegakkan amar makruf nahi mungkar.

Dengan memiliki keistiqomahan, pemimpin dan ulama dalam mengamalkan ajaran Islam, akan menjadi tolak ukur kemajuan peradaban dan perkembangan umat. Dengan selalu menegakkan dan menyampaikan peringatan dari Allah swt.

FirmanNya :

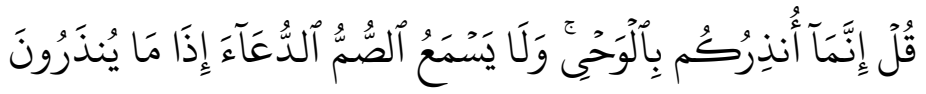

Maksudnya: "Katakanlah (hai Muhammad): "Sesungguhnya aku hanya memberi peringatan kepada kamu sekalian dengan wahyu dan tiadalah orang-orang yang tuli mendengar seruan, apabila mereka diberi peringatan"(QS. Al-Anbiya : 45)

\section{PENUTUP}

Dari uraian dan penjelasan di atas, perlu diberikan beberapa penekanan dalam kesimpulan bahwa, ibadah merupakan kepatuhan dan ketaatan manusia dalam segala bidang dan gerak-gerik kepada Allah SWT. Tujuannya ialah untuk kebersihan jiwa kemurnian hati, menimbulkan kemesraan hubungan dan kecintaan kepada Allah serta membina ketinggiannya budi dan keluhuran amal. Tuntutan jalan yang diberikan oleh para ulama mengambarkan adanya hubungan amal ibadah dengan ketauhidan, yang melambangkan iman dan keyakinan itulah yang disebut dengan akidah Islamiah. Dengan tetap mejaga akhlak dan kepribadian Islam sebagaimana dijelaskan oleh Allah dalam al-Quran serta Sunnah Rasulullah saw, maka kolaborasi dakwah yang dilaksanakan oleh ulama dan umara akan selalu dilindungi oleh Allah swt. Hal ini merupakan salah satu bentuk dari sifat-sifat akhlak pemimpin yang dicintai oleh rakyat dan umat.

Maka seorang pemimpin (umara) dan kaum yang 'alim (ulama) merupakan sosok yang dapat meyakinkan akan kualitas yang disebutkan itu. Umara dan ulama dua sisi peran yang berbeda akan tetapi tujuannya dapat 
disamakan yakni menuntun umat ke jalan yang benar dan di ridhai oleh Allah swt dan Rasul-Nya.

\section{DAFTAR PUSTAKA}

Al Ghazali, M. (1996). Tujuan Hidup Para Sufi, Cet Ke-1. Selangor: Pustaka Ilmi.

A'la Al-Maududi. A. (1991). Mencari Jalan Selamat (Salim Basyarah, Penerjemah), Cet Ke-1. Jakarta: Gema Insani.

Amin Abdul Azizi. J. (2000). Fiqh Dakwah Cet Ke- 1. Surakarta: Era Intermedia.

Hawwa, S. (1988). Jundullah Tsaqafatan wa Akblaqan, (Abu Ridha, Penerjemah), Cet Ke 1. Jakarta: al-Ishlahy Press dan Thinker's Library.

Kementerian Pendidikan Malaysia. (1994). Kamus Dewan, Cet Ke-1. Kuala Lumpur: Dewan Bahasa dan Pustaka.

Mustafa al-Maraghi, A. (1987). Tafsir al-Maraghi (Hery Noer Aly dkk, Penerjemah). Semarang: Toha Putra.

Natsir. M. (1973). Capita Selecta, Cet Ke-1. Jakarta: Bulan Bintang.

Othman, R. (1990). Pengurusan Dakwah, Cet Ke-1. Selangor: Polycgrafhic Press.

Rasyid, H. (2007). Bimbingan Ulama Kepada Umara dan Umat, Cet Ke-1. Jakarta: Pustaka Beta.

Yunan Nasution. M. (1988). Islam dan Problema-problema Kemasyarakatan, Cet Ke-1. Jakarta: Bulan Bintang. 